\title{
INFORMATION TECHNOLOGY UTILIZATION AND INTERNAL CONTROL ACCOUNTING FOR THE VALUE OF FINANCIAL REPORTING INFORMATION
}

\author{
${ }^{1}$ Siti Rahmayuni, ${ }^{2}$ Anwar Arifin Pinem \\ ${ }^{1,2}$ STIE Balikpapan, Balikpapan, Indonesia \\ Emaol: ${ }^{1}$ yuni@stiebalikpapan.ac.id, ${ }^{2}$ anwar@stiebalikpapan.ac.id
}

\begin{abstract}
Purpose: of this research is to know the effect of utilization of information technology and internal control of accounting for the value of financial reporting information

Design/methodology/approach: quantitative methods using multiple linear regression methods.

Findings: Utilization of Information Technology, internal accounting controls have a significant effect on the value of financial reporting information at the Center for Research and Development of Natural Resources Conservation Technology, East Kalimantan.
\end{abstract}

Research limitations/implications: Utilization of Information Technology, internal accounting controls.

Practical implications: Results show that from the 2 hypothesis proposed.

Originality/value: This paper is original.

Paper type: Research paper

Keyword: Information Technology, Internal Control, Accounting., Financial.

Received: July $15^{\text {th }}, 2020$

Revised: September $18^{\text {th }}, 2020$

Published: September $30^{\text {th }}, 2020$

\section{INTRODUCTION}

Technological developments are needed to obtain accurate and reliable information, utilization of information technology, especially reports relating to financial information in accordance with the regulations in the State budget. Relevant information requires timeliness, which must be met in order for financial statements to be presented for decision makers.

The Government is obliged to observe the information presented in the financial statements for planning, control and utilization purposes. Accounting information contained in government financial statements must have some qualitative requirements to be used as guidelines and normative measures that need to be realized and fulfill their objectives. The head and/or chief of a government agency that is as a user of financial statements requires timely value and information to facilitate and enable them to conduct analysis and make a proper decision. The application of information technology is related to the condition of hardware, software used, data recovery, human resource capacity that implements the accounting system and the availability of funds and or financial. This is a factor in the utilization of information technology in government agencies is not optimal, so it has an influence on the value, reliability and timeliness of government financial reporting.

Implementation of accounting internal control system requires active role and commitment of the leaders in an organization.Current problems not yet effective government internal control includes the problem of lack of orderly arrangement and application of policies and lack of commitment to competence 
and not optimal identification and risk analysis, weak physical control of assets, to the recording of transactions that are less accurate and timely.

\section{LITERATURE REVIEW}

The main purpose of technology is the provision of information for a variety of managerial activities and the provision of money information needed in various levels of operations within the organization

The benefits offered by information technology, such as transaction processing speed and report preparation, accuracy of calculations, large amounts of data storage, lower kost processing, functions capability, but the implementation of information technology is not cheap, if the information technology is not and or has not been utilized to the fullest, it becomes useless and will be more expensive

(Bouhnik and Carmi, 2012) Technological skills is a must to take part in online work, Technology helps every job becomes easy without having to use long time, with the work technology can be done anywhere and anytime.

(Chalmers, Hay and Khlif, 2019) Internal quality Control suggests that the quality of internal control can have a significant impact on decision-making by users of financial information. Internal controls generally support positive relationships and the benefits of management and auditors to report internal control over financial reporting

Internal control includes all organizational policies and procedures that guarantee the security of the company's wealth, accuracy and feasibility of management data as well as other standards of management operations. The term commonly used for internal control is internal control system, internal surveillance system and internal control structure.

(Iatridis, 2010) IFRSs reduces coverage for revenue management, associated with more timely loss recognition and leads to more relevant accounting step values. This suggests that information less asymmetry and revenue manipulation will lead to the disclosure of accounting information quality and higher informative and therefore will help investors in making informed judgments and unbiased

Based on opinion (Bouhnik and Carmi, 2012) on the use of Information technology, (Chalmers, Hay and Khlif, 2019) Internal quality control and (Iatridis, 2010) IFRSs then need to be learned about previous research discussing such variables to convince what we thoroughly fit or not with prior research

(Kuhn and Sutton, 2010) the market does not necessarily understand and respond to the effects of IT weaknesses on overall financial performance of firms and thus challenge the efficient market hypothesis theory. (Zelbst et al., 2010) Timely information must be provided for all supply chainsPartners that support linking and syncing, (Morton and $\mathrm{Hu}, 2008$ ). Data collection and automatic tracking systems such as radio frequency identification (RFID), when utilized with ERP systems, facilitate information sharing throughout the supply chain, which has the potential to enhanced supply chain performance. When successfully implemented, information sharing provides the necessary operational, tactical, and strategic information to supply chain partners on a real-time, synchronous basis utilizing the data capturing capabilities of technologies such as RFID. Generally, we propose that RFID technology utilization supports supply chain information sharing (SCIS) which in turn improves the overall performance of the entire supply chain.

For the benefit and purpose of drafting government financial statements can be fulfilled then the information presented must be useful information for interested parties with such information

(Nogueira and Jorge, 2017) Internal municipal user attitudes towards the use of accrual-based financial reporting for changing decision making. In addition, internal decision makers consider financial and budgetary information as very useful for decision making, and the different types of internal controls that apply to critical information. Results also clearly indicate a significant and positive relationship between internal controls (including internal audits) that financial and budgetary information is subject to, and perceived usability for municipal decision-making.

The results of studies by (Andriani, Kober and Ng, 2010). (Kober, Lee and Ng, 2010), and (Bergmann, 2012) have showed that the degree of usefulness of the obligatory financialreporting for public sector entities, based on business sector reporting, has beenchanging, such that it is now perceived among several users as more useful.

Specifically, the study by (Bergmann, 2012) in Switzerland, with the purpose ofanalysis the influence of financial reporting on decision-making, revealed thatfinancial reporting, namely information prepared according to accrual accounting, aimsfundamentally to support decision-making. 


\section{METHODOLOGY}

The method used in this research is a descriptive method with a survey approach, covering; (a). The statistic is to function to describe or provide an overview of the objects examined through the sample data or population as they are. (b) The statistical survey is a process of collecting the primary data by asking questions to obtain the necessary information.

Since the research is conducted on an organization only and the problems studied are specific, then the operational object of this research is the free variable or what is the attention point of a writing, while the variable subject is the place where the variable is attached. The operational object of this research is the influence of human resources, the utilization of information technology and internal control of Accounting, Questions, hypotheses and research methods

The main purpose of this study is to determine whether the perceived influence of information technology utilization and internal control accounting for the value of financial reporting information. In order to accomplish thisObjectives, the following research questions are defined:

Does the utilization of information technology and internal control of accounting affect the value of financialreporting information?

H1: Utilization of information technology to the value of financial reporting information

$\mathrm{H} 2$ : Internal control over the value of financial reporting information

\section{A. Population, Data And Sample}

The population was taken from the Office of Research and Development of natural resources conservation Technology of East Kalimantan with samples of 65 employees in several districts.

\section{RESULTS AND DISCUSSION}

Based on the hypotheses and the literature discussed in the previous chapter, it can be analyzed that the following hypotheses results

\section{H1: Utilization of information technology to the value of financial reporting information}

Based on the results of the analysis obtained the value of partial correlation coefficient (r) on the utilization of Information technology (X1) variable amounting to 0.603 and the calculated T value of $5.910>$ $\mathrm{T}$ table 1.99 on SIG $0.000<0.005$ showed that the information technology Utilization (X1) variable has a significant influence on the value of financial reporting information (Y) on the Office of Research and Development of natural resources conservation Technology of East Kalimantan

\section{$\mathrm{H} 2$ : Internal control over the value of financial reporting information}

Result of analysis obtained the value of partial correlation coefficient (r) on the variable internal Control accounting (X2) amounting to 0.357 and the calculated T value of $2.985>$ T table 1.99 on SIG $0.004<0.05$ indicates that the variable internal accounting control (X2) has a significant effect on the value of financial reporting information $(\mathrm{Y})$ on the Office of Research and Development of natural resources conservation Technology of East Kalimantan

Analysis results show that the value of the partial correlation coefficient ( $\mathrm{r}$ ) as well as the test $\mathrm{T}$ test where the utilization of information technology (X2) variable has a value greater than the other variable values it indicates that the utilization of information technology (X2) has an influence on the value of financial reporting information (Y) in the Office of Research and Development of natural resources conservation Technology of East Kalimantan then based on the analysis and discussion of the second hypothesis is acceptable and proven correct.

The results showed that there was conformity between previous research and the ongoing research, that each variable positively and significantly affected

And for further research should increase the research scope for the central government of Indonesia

Table 1. Simultaneous analysis Results

\begin{tabular}{llllll}
\hline KoefisienKorelasi R & Calculate T & Calculate F & F tabel & Sig & Description \\
\hline
\end{tabular}

Information Technology Utilization And Internal Control Accounting For The Value Of Financial 


\begin{tabular}{cccccc}
\hline \hline 0,948 & 0,899 & 81,159 & 2,70 & 0,000 & signifikan \\
\hline
\end{tabular}

Data Source: Analysis results using SPSS

Table 2. Partial analysis results

\begin{tabular}{|c|c|c|c|c|c|c|}
\hline $\begin{array}{lllll}\text { Variabel. Calculate } & \text { T } & \text { Table } & \text { Sig } \\
\text { description } & & & & \end{array}$ & $\begin{array}{l}\text { coefficient } \\
\text { regression } \mathrm{B}\end{array}$ & $\begin{array}{l}\text { coefficient } \\
\text { correlation }(\mathrm{r}) \\
\mathrm{T}\end{array}$ & $\begin{array}{l}\text { Calcula } \\
\text { te } \mathrm{T}\end{array}$ & $\mathrm{t}$ tabel & Sig & Description \\
\hline $\begin{array}{l}\text { Value of financial reporting information } \\
\text { (Y) }\end{array}$ & 0,708 & & & & & \multirow{3}{*}{$\begin{array}{l}\text { Significant } \\
\text { Significant }\end{array}$} \\
\hline $\begin{array}{l}\text { Constant } \\
\text { Utilization of Information technology } \\
\text { (X1) }\end{array}$ & 0,374 & 0,603 & 5,910 & 1,99 & 0,000 & \\
\hline Internal control Accounting (X2)) & 0,214 & 0,357 & 4,985 & 1,99 & 0,004 & \\
\hline
\end{tabular}

Data Source: Analysis results using SPSS

Based on a regression coefficient acquired multiple linear regression equations:

$$
Y=0,393+0,194 X_{1}+0,445 X_{2}+0,298 X_{3}
$$

Table 3. Results of the classic assumption violation

\begin{tabular}{|c|c|c|c|c|c|c|}
\hline Variabel & $\begin{array}{l}\text { Koefisien } \\
\text { Beta }\end{array}$ & Keterangan & VIF & Keterangan & $\begin{array}{l}\text { Durbin } \\
\text { Watson }\end{array}$ & Keterangan \\
\hline $\begin{array}{l}\text { Value of financial } \\
\text { reporting } \\
\text { information (Y) } \\
\text { Constant } \\
\text { Utilization of } \\
\text { Information } \\
\text { technology (X1) } \\
\text { Internal control } \\
\text { Accounting (X2) }\end{array}$ & $\begin{array}{l}0,399 \\
0,245\end{array}$ & $\begin{array}{l}\text { No Heteroskedastis } \\
\text { happening } \\
\text { Because the beta } \\
\text { coefficient }> \\
0.05\end{array}$ & $\begin{array}{l}2,75 \\
3 \\
4,09 \\
0\end{array}$ & $\begin{array}{l}\text { Not happening } \\
\text { Multikolinearity } \\
\text { Because the VIF } \\
\text { value is below } 5\end{array}$ & 2,359 & $\begin{array}{l}\text { Not } \\
\text { Happen } \\
\text { Autocorrelation } \\
\text { Because it is in the } \\
\text { autocorrelation free } \\
\text { Area } \\
\text { DW } 1.69 \mathrm{~S} / \mathrm{d} 2.39\end{array}$ \\
\hline
\end{tabular}

Data Source: Analysis results using SPSS

\section{CONCLUSION}

The Information Technology Utilization (X1) variable has a significant and dominant influence on the value of financial reporting information (Y) of the Office of Research and Development of natural resources conservation Technology of East Kalimantan, hence the second hypothesis can be accepted and proven truthfulness. That an internal accounting control (X2) variable has a significant influence on the value of financial reporting information (Y) of the Office of Research and Development of natural resources conservation Technology of East Kalimantan Hence the second hypothesis is acceptable and proven correct.

Double linear regression Model can be used as proof tool for hypotheses because there is no violation of the classic assumption.

\section{REFERENCES}

Andriani, Y., Kober, R. and Ng, J. (2010) 'Decision Usefulness of Cash and Accrual Information: Public Sector Managers' Perceptions', Australian Accounting Review, 20(2), pp. 144-153. doi: 10.1111/j.18352561.2010.00087.x.

Bergmann, A. (2012) 'The influence of the nature of government accounting and reporting in decisionmaking: Evidence from Switzerland', Public Money and Management, 32(1), pp. 15-20. doi: 10.1080/09540962.2012.643050. 
Bouhnik, D. and Carmi, G. (2012) 'E-learning environments in academy: Technology, pedagogy and thinking dispositions', Journal of Information Technology Education:Research, 11(1), pp. 201-219. doi: $10.28945 / 1698$.

Chalmers, K., Hay, D. and Khlif, H. (2019) 'Internal control in accounting research: A review', Journal of Accounting Literature, 42(c), pp. 80-103. doi: 10.1016/j.acclit.2018.03.002.

Iatridis, G. (2010) 'International Financial Reporting Standards and the quality of financial statement information', International Review of Financial Analysis, 19(3), pp. 193-204. doi: 10.1016/j.irfa.2010.02.004.

Kober, R., Lee, J. and Ng, J. (2010) 'Mind Your Accruals: Perceived Usefulness Of Financial Information In The Australian Public Sector Under Different Accounting Systems', Financial Accountability \& Management, 26(3), pp. 267-298. doi: 10.1111/j.1468-0408.2010.00502.x.

Kuhn, J. R. and Sutton, S. G. (2010) 'Continuous auditing in ERP system environments: The current state and future directions', Journal of Information Systems, 24(1), pp. 91-112. doi: 10.2308/jis.2010.24.1.91.

Morton, N. A. and $\mathrm{Hu}, \mathrm{Q}$. (2008) 'Implications of the fit between organizational structure and ERP: A structural contingency theory perspective', International Journal of Information Management, 28(5), pp. 391-402. doi: 10.1016/j.ijinfomgt.2008.01.008.

Nogueira, S. P. da S. and Jorge, S. M. F. (2017) 'The perceived usefulness of financial information for decision making in Portuguese municipalities', Journal of Applied Accounting Research, 18(1), pp. 116-136. doi: 10.1108/JAAR-05-2014-0052.

Zelbst, P. J. et al. (2010) 'RFID utilization and information sharing: The impact on supply chain performance', Journal of Business and Industrial Marketing, 25(8), pp. 582-589. doi: 10.1108/08858621011088310. 